\title{
A Case of Ancylostoma ceylanicum Infection Occurring in an Australian Soldier Returned from Solomon Islands
}

\author{
Rick Speare ${ }^{1,2}$, Richard Stewart Bradbury ${ }^{3, *}$, John Croese $^{4}$ \\ ${ }^{1}$ College of Public Health, Veterinary and Medical Sciences, James Cook University, Townsville, Australia; ${ }^{2}$ Tropical Health Solutions Pty Ltd, Topaz, \\ Australia; ${ }^{3}$ School of Medical and Applied Sciences, Central Queensland University, North Rockhampton, Australia; ${ }^{4}$ Department of Gastroenterology \\ and Hepatology, The Prince Charles Hospital, Brisbane, Australia
}

\begin{abstract}
A 26-year-old male member of the Australian Defense Force presented with a history of central abdominal pain of 4 weeks duration and peripheral eosinophilia consistent with eosinophilic enteritis. Acute hookworm disease was diagnosed as the cause. Adult worms recovered from feces after therapy with albendazole were morphologically consistent with Ancylostoma ceylanicum. As the patient had been deployed with the Regional Assistance Mission to Solomon Islands for 6 months prior to this presentation, it is very likely that the $A$. ceylanicum was acquired in Solomon Islands. Until now, it has been assumed that any Ancylostoma spp. recovered from humans in Solomon Islands is $A$. duodenale. However, this case demonstrates that human hookworm infection acquired in the Solomon Islands could be caused by $A$. ceylanicum.
\end{abstract}

Key words: Ancylostoma ceylanicum, hookworm, Solomon Islands, eosinophilic enteritis

\section{INTRODUCTION}

Humans are infected naturally by 3 species of hookworms; Necator americanus, Ancylostoma duodenale, and Ancylostoma ceylanicum [1]. Individual people can be infected with 1 species, 2 species, or all 3 species of hookworms [1-5]. Although A. ceylanicum is often considered to be a zoonotic pathogen, since it is also found in dogs and cats, its importance as a significant soil-transmitted helminth of humans is increasingly being recognized [1]. Two haplotypes of A. ceylanicum have been identified; one largely found in humans and another that infects humans, dogs, and cats $[5,6]$.

A. ceylanicum is considered to be of emerging importance as a helminth of humans in the Asia Pacific region [1]. A fourth hookworm also reported from humans, Ancylostoma caninum represents a canine species with zoonotic potential. This species has mainly been recorded as causing eosinophilic enteritis in people in tropical Australia, but never establishes a patent infection and hence humans are regarded as accidental hosts [7].

- Received 15 May 2016, revised 17 June 2016, accepted 20 June 2016.

*Corresponding author (r.bradbury@cqu.edu.au)

(c) 2016, Korean Society for Parasitology and Tropical Medicine

This is an Open Access article distributed under the terms of the Creative Commons Attribution Non-Commercial License (http://creativecommons.org/licenses/by-nc/4.0) which permits unrestricted non-commercial use, distribution, and reproduction in any

medium, provided the original work is properly cited.
Human hookworm is common in the Solomon Islands, with an estimated 192,000 people (36\% of the population) infected [8], but the different species involved are yet to be determined [9-11]. The report to the Rockefeller hookworm campaign in 1928 described only N. americanus as being present on these islands [12]. The only previous report of A. ceylanicum from the Solomon Islands was a 5-year-old boy who imported the species in 1938 from the Shortland Island group of the Solomon Islands to Australia [13].

The Solomon Islands is a small Pacific nation to the North East of Australia, with a predominantly Melanesian population. The Regional Assistance Mission to Solomon Islands (RAMSI) occurred between 2003 and 2013, at the request of the Solomon Island's government, to assist in stabilizing internal troubles occurring within the nation. RAMSI consisted of 2,200 police and soldiers from many Pacific Island nations and was led by Australia. This case report describes the finding of A. ceylanicum in an Australian soldier who developed symptomatic disease after returning from a deployment in Solomon Islands with RAMSI

\section{CASE RECORD}

The patient was a 26-year-old male living in Townsville, north Queensland, Australia who presented in March 2004 

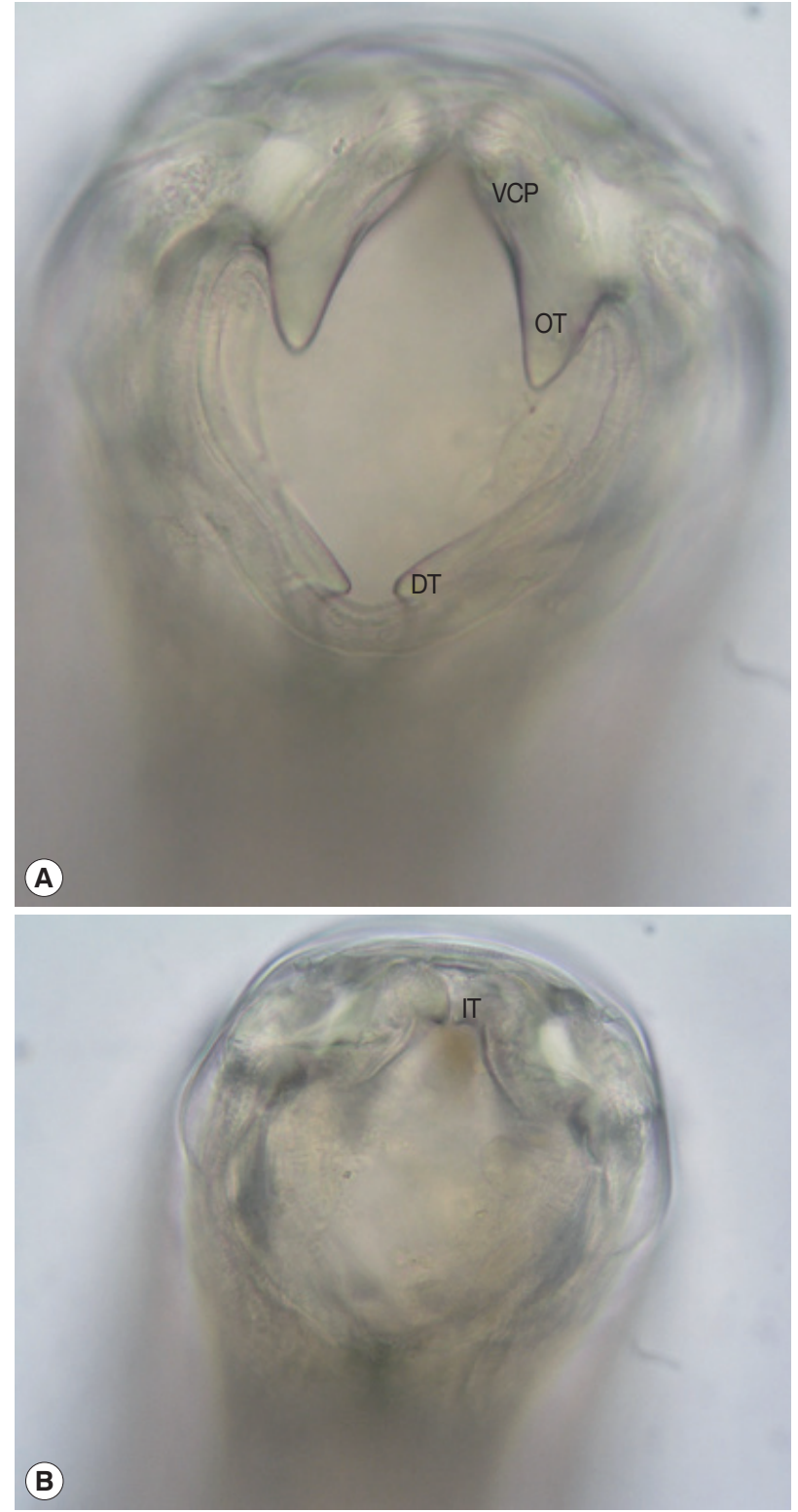

Fig. 1. En face view of the mouth part of an adult female Ancylostoma ceylanicum recovered from feces. (A) Robust ventral cutting plate with prominent outer tooth. (B) Optical section through a more posterior plane to show the smaller inner tooth on cutting plate. VCP, ventral cutting plate; OT, outer tooth; DT, dorsal tooth; IT, inner tooth. $\times 400$ magnification.

with central poorly defined abdominal pain of 4 weeks duration and increased frequency of defecation. A peripheral eosinophilia had been noted on blood tests in February prior to symptom development, and in March, when eosinophils were $6.20 \times 10^{\circ} / \mathrm{L}$ whilst red blood cell indices were normal (hemoglobin $146 \mathrm{~g} / \mathrm{L}, \mathrm{MCV} 93 \mathrm{fL}$, hematocrit 0.44 , red cell count $4.7 \times 10^{12} / \mathrm{L}$ ). The patient had served with RAMSI in the Solo-

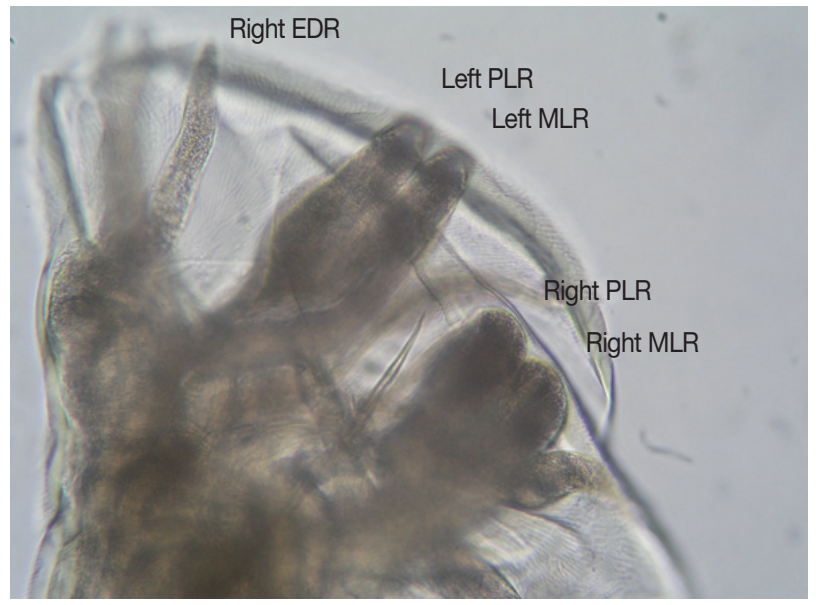

Fig. 2. Lateral view of the bursa of an adult male Ancylostoma ceylanicum. Note the parallel mediolateral and posteriolateral rays. EDR, externodorsal ray; MLR, mediolateral ray; PLR, posteriolateral ray. $\times 400$ magnification.

mon Islands from late July to early December 2003. His duties involved travel to various remote areas and provided multiple opportunities to become infected with hookworms. Routine treatment with albendazole had been given by the Australian Defense Force on return to Townsville in December, 2 months prior to development of symptoms. Initially, in March 2004 no parasite eggs were detected in feces by formalin-ethyl acetate concentration, but infective larvae of hookworms were found on Harada-Mori culture. Subsequently, typical thinshelled hookworm eggs were detected on direct fecal smears. Infective larvae were sheathed, had inconspicuous buccal spears, the intestine was narrower than the esophageal bulb, and inconspicuous transverse striations were noted on the sheath in the tail region. The infective larvae, measured after preservation in hot formalin, had the following dimensions, mean \pm SD (range): length 657.1 $\pm 9.6 \mu \mathrm{m}(633-669 \mu \mathrm{m})$, width $21.4 \pm 0.9 \mu \mathrm{m}(20.2-22.2 \mu \mathrm{m})$, esophagus $156.7 \pm 3.5$ $\mu \mathrm{m}(151-162 \mu \mathrm{m})$, tail $77.9 \pm 3.8 \mu \mathrm{m}(69-81 \mu \mathrm{m})$, length of sheath $763.7 \pm 8.6 \mu \mathrm{m}(779-746 \mu \mathrm{m})$; esophagus/length $23.8 \pm 0.5 \%$, and tail/length $11.9 \pm 0.6 \%$.

Due to the failure of single dose post-deployment albendazole therapy to eradicate this infection, the patient was treated with $100 \mathrm{mg}$ of mebendazole twice daily for 3 days. Twelve adult hookworms ( 6 females and 6 males) were recovered by dissection of stools passed during the $48 \mathrm{hr}$ immediately following treatment. The en face view revealed a robust ventral cutting plate bilaterally with a prominent point on the dorsal end and less obvious point on the ventral end (Fig. 1). The 
width of the bursa in lateral view was greater than its length, and the mediolateral and posteriolateral bursal rays were parallel (Fig. 2). The patient responded well to the treatment and became asymptomatic.

\section{DISCUSSION}

The morphology of the adult hookworms was consistent with A. ceylanicum with key features being: the large ventral cutting plates terminating at the dorsal end in a large single tooth; and in the male the parallel mediolateral and posteriolateral bursal rays [14]. Although the morphology and dimensions of the infective larvae are more consistent with A. ceylanicum than N. americanus [15], differentiating them from infective larvae of $A$. duodenale is unreliable. Although molecular taxonomy is valuable in identifying hookworm species [16], it was not available in this case and, as the specimen was subsequently accidentally disposed of, molecular taxonomic studies cannot be performed now. However, the morphological features were sufficient to identify this species as A. ceylanicum. This represents only the second report of human A. ceylanicum infection having been acquired in this nation, with the first being made almost 80 years ago [13]. This finding not only expands the known range of human A. ceylanicum infection but also raises the question of whether A. ceylanicum is in fact a common cause of human hookworm infection in some regions of the Solomon Islands, as it has recently been described as being in many parts of Asia [1]. The only previous reported description of hookworm species in the country was almost 80 years ago and was anecdotal, not providing descriptions of number of people tested or how the species identifications were arrived at [12].

A. ceylanicum infection has recently been reported from two people in Western Australia [17]. Prior to this, A. ceylanicum had been reported from dogs and cats in northern Australia, including those from Townsville $[18,19]$. Hence, the infection could have been acquired in north Queensland or while deployed with RAMSI. The likelihood of infection with Ancylosto$m a$ from humans in the Solomon Islands is high, but negligible in north Queensland since human feces are disposed of safely. However, since A. ceylanicum is present in dogs and cats in north Queensland, there is a possibility of a zoonotic Australian source even though this infection has not been seen in humans in this region. Many RAMSI personnel were infected with hookworms during their mission to the Solomon Islands, and an isolated case of A. ceylanicum infection had been reported from this area early in the 20th century. This adds to the likelihood that the case presented here was acquired in the Solomon Islands and not elsewhere [20,21].

The clinical symptoms displayed by our patient were consistent with the phase of hookworm infection during which the host attempts to eliminate the parasite using an allergic response, manifesting morphologically as eosinophilic enteritis [22]. For $N$. americanus this response begins about 10 days after infection and persists for up to a month [22]. A. caninum and $A$. duodenale have a more complicated life cycle in which some infective larvae can enter a state of hypobiosis (arrested development) and can orchestrate entry to the intestine to coincide with the wet season and physiological events [23-26]. Whether A. ceylanicum has this capacity is unknown. The failure of a routine post-deployment albendazole treatment to eliminate the infection in our patient supports a hypothesis that the current infection was due to hypobiotic larvae activated after the anthelmintic was given. The north Queensland wet season commences in late December. Acute enteritis has been described previously in soldiers with A. ceylanicum acquired in West Papua (formerly Dutch New Guinea) [3] and in a traveller returning from Myanmar to France [16]. Treatment with albendazole in the latter patient cleared the gut infection but symptoms and parasites recurred after 3 months adding evidence for hypobiosis in A. ceylanicum. Our patient was treated after diagnosis with mebendazole due to its far greater tissue penetration and therefore greater capacity to kill hypobiotic larvae in the tissue.

The key points from this case report are: A. ceylanicum should be considered as a cause of acute eosinophilic enteritis in returned travellers, workers, or defense force personnel who have lived or visited tropical and subtropical countries; laboratory confirmation may require persistence to make the diagnosis of hookworms and will require special tests (morphology of adults after treatment; molecular taxonomy on stools or infective larvae) to identify the species; and human infection with A. ceylanicum is probably endemic in the Solomon Islands and further study of the prevalence of different hookworm species present in this country is warranted.

\section{CONFLICT OF INTEREST}

We have no conflict of interest related to this work. 


\section{DEDICATION}

This paper is dedicated to the memory of Emeritus Professor Rick Speare, whose passing is a great loss to Parasitology in Australia, the Pacific region and the world.

\section{REFERENCES}

1. Traub RJ. Ancylostoma ceylanicum, a re-emerging but neglected parasitic zoonosis. Int J Parasitol 2013; 43: 1009-1015.

2. Lane HC. Ancylostoma ceylanicum, a new human parasite. Ind Med Gaz 1913; 48: 216-218.

3. Anten JF, Zuidema PJ. Hookworm infection in Dutch servicemen returning from West New Guinea. Trop Geogr Med 1964; 16: 216-224.

4. Ngui R, Lim YA, Traub R, Mahmud R, Mistam MS. Epidemiological and genetic data supporting the transmission of Ancylostoma ceylanicum among human and domestic animals. PLoS Negl Trop Dis 2012; 6: e1522.

5. Inpankaew T, Schär F, Dalsgaard A, Khieu V, Chimnoi W, Chhoun C, Sok D, Marti H, Muth S, Odermatt P, Traub RJ. High prevalence of Ancylostoma ceylanicum hookworm infections in humans, Cambodia, 2012. Emerg Infect Dis 2014; 20: 976-982.

6. Ngui R, Mahdy MA, Chua KH, Traub R, Lim YA. Genetic characterization of the partial mitochondrial cytochrome oxidase $\mathrm{c}$ subunit I (cox 1) gene of the zoonotic parasitic nematode, Ancylostoma ceylanicum from humans, dogs and cats. Acta Trop 2013; 128: 154-157.

7. Croese J, Fairley S, Loukas A, Hack J, Stronach P. A distinctive aphthous ileitis linked to Ancylostoma caninum. J Gastroenterol Hepatol 1996; 11: 524-531.

8. Kline K, McCarthy JS, Pearson M, Loukas A, Hotez PJ. Neglected tropical diseases of Oceania: review of their prevalence, distribution, and opportunities for control. PLoS Negl Trop Dis 2013; 7: e1755.

9. Hughes RG, Sharp DS, Hughes MC, Akau'ola S, Heinsbroek P, Velayudhan R, Schulz D, Palmer K, Cavalli-Sforza T, Galea G. Environmental influences on helminthiasis and nutritional status among Pacific schoolchildren. Int J Environ Health Res 2004; 14: 163-177.

10. Hsiao SHM, Tsai JJ, Wu LK, Dalipanda T, Lai WT. The prevalence of skin/soil transmitted helminthiasis in Melanesian community. 16th International Congress on Infectious Diseases, Capetown, South Africa, 2-5 April 2014. Abstract 45.003. (http:// www.xcdsystem.com/icid2014/45.003.html, accessed 28 January 2015).

11. Harrington H, Bradbury R, Taeka J, Asugeni J, Asugeni V, Igeni T, Gwalaa J, Newton L, Fàanuabae CE, Kilivisi FL, Esau D, Flores A, Ribeyro E, Liku D, Muse A, Asugeni L, Telene J, Shield J, MacLar- en DJ, Massey PD, Muller R, Speare R. Prevalence of soil transmitted helminths in remote villages in East Kwaio, Solomon Islands. West Pacific Surveillance Response J 2015; 6.

12. Lambert SM. Medical conditions in the South Pacific. Med J Aust 1928; 2: 362-378.

13. Haydon GAM, Bearup AJ. Ancylostoma braziliense and A. ceylanicum. Trans Roy Soc Trop Med Hygiene 1963; 57: 76.

14. Traub RJ, Hobbs RP, Adams PJ, Behnke JM, Harris PD, Thompson RC. A case of mistaken identity--reappraisal of the species of canid and felid hookworms (Ancylostoma) present in Australia and India. Parasitology 2007; 134: 113-119.

15. Yoshida Y. Comparative studies on Ancylostoma braziliense and Ancylostoma ceylanicum. II. The infective larval stage. J Parasitol 1971; 57: 990-992.

16. Brunet J, Lemoine JP, Lefebvre N, Denis J, Pfaff AW, Abou-Bacar A, Traub RJ, Pesson B, Candolfi E. Bloody diarrhea associated with hookworm infection in traveler returning to France from Myanmar. Emerg Infect Dis 2015; 21: 1878-1879.

17. Koehler AV, Bradbury RS, Stevens MA, Haydon SR, Jex AR, Gasser RB. Genetic characterization of selected parasites from people with histories of gastrointestinal disorders using a mutation scanning-coupled approach. Electrophoresis 2013; 34: 1720-1728.

18. Stewart L. The taxonomy of Ancylostoma species in the Townsville region of North Queensland. MSc thesis, James Cook University, Australia. 1994.

19. Palmer CS, Traub RJ, Robertson ID, Hobbs RP, Elliot A, While L, Rees R, Thompson RC. The veterinary and public health significance of hookworm in dogs and cats in Australia and the status of A. ceylanicum. Vet Parasitol 2007; 145: 304-313.

20. Pattison D, Speare R. Strongyloidiasis in participants of the Regional Assistance Mission to Solomon Islands (RAMSI). Med J Aust 2008; 189: 203-206.

21. Visser JT, Narayanan A, Campbell B. Strongyloides, dengue fever, and tuberculosis conversions in New Zealand police deploying overseas. J Trav Med 2012; 19: 178-182.

22. Croese J, Speare R. Intestinal allergy expels hookworms: seeing is believing. Trends Parasitol 2006; 22: 547-550.

23. Schad GA, Chowdhury AB, Dean CG, Kochar VK, Nawalinski TA, Thomas J, Tonascia JA. Arrested development in human hookworm infections: an adaptation to a seasonally unfavorable external environment. Science 1973; 180: 502-504.

24. Nawalinski TA, Schad GA. Arrested development in Ancylostoma duodenale: course of a self-induced infection in man. Am J Trop Med Hyg 1974; 23: 895-898.

25. Prociv P, Luke RA. Evidence for larval hypobiosis in Australian strains of Ancylostoma duodenale. Trans R Soc Trop Med Hyg 1995; 89: 379.

26. Dryanovski DI, Dowling C, Gelmedin V, Hawdon JM. RNA and protein synthesis is required for Ancylostoma caninum larval activation. Vet Parasitol 2011; 179: 137-143. 